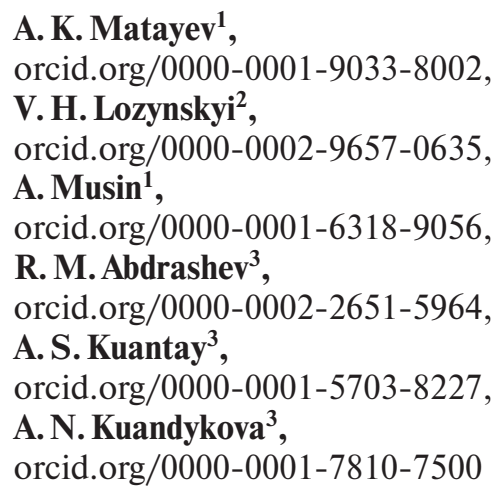

1 - Karaganda Technical University, Karaganda, the Republic of Kazakhstan, e-mail: mataev.azamat@mail.ru

2 - Geological Concern "Geobit", Chrzanow, the Republic of Poland

3 - Aktobe Regional University named after K. Zhubanov, Aktobe, the Republic of Kazakhstan

\title{
SUBSTANTIATING THE OPTIMAL TYPE OF MINE WORKING FASTENING BASED ON MATHEMATICAL MODELING OF THE STRESS CONDITION OF UNDERGROUND STRUCTURES
}

Purpose. Predicting the formation of a stress-strain state (SSS) in the rock mass within the boundaries of influence of stope operations on the horizon $-480 \mathrm{~m}$ in axes $20-28$ at the $10^{\text {th }}$ Anniversary of Kazakhstan's Independence (DNK) Mine.

Methodology. An engineering-geological data on the host rocks properties are analyzed based on the international ISRM standard. Numerical modelling of the rock mass stress-strain state and the calculation of the load-bearing capacity of the compound support (roof-bolt + shotcrete + mesh) and arch support used at the mine are performed with the help of the RS2 software. This program, based on the Finite Element Method in a two-dimensional formulation, makes it possible to take into account a significant number of factors influencing the rock mass state.

Findings. The calculations performed indicate that the support resistance is incommensurably low in comparison with the values of the initial stress field components in the rock mass. In such conditions, it may be more effective to strengthen the mass in the vicinity of mine working than setting more frames or using more massive support profiles.

Originality. The paper presents the results of mathematical modeling and calculation of the stress-strain state of the underground "supporting - aquifer rock mass" structures developed for complex mining-and-geological and geomechanical conditions of driving, supporting and operating mine workings on deep horizons of the mines at Donskoy Ore Mining and Processing Plant. Based on the performed research, the preliminary (advanced) strengthening of the border rock mass in the zone of inelastic (destructive) deformations has been substantiated, as a priority method to control the stability of mine workings.

Practical value. The research results can be used when creating a geomechanical model of the field and designing stable parameters of mine working support.

Keywords: mine, mine working fastening, stress-strain state, zone of inelastic deformations, frame support

Introduction. Mining operations are becoming more complicated with an increase in the depth of mining and, accordingly, with an increase in rock pressure. The study on rock pressure manifestation in the advance workings has received considerable attention, because it is crucial for their stability and maintenance. The degree of stability is influenced by a number of factors: rock strength, the degree of the rock mass fracturing, fracture opening, fracture wall roughness, fracture filling, rock water cut, and others [1]. Substantiation of the optimal fastening type for mine working is a difficult task, but a necessary one.

The geomechanical conditions of the mines at Donskoy Ore Mining and Processing Plant (DGOK) are typical for most chromite deposits confined to highly fractured hard rock mass of ultrabasic composition: serpentinites through dunites, amphibolite, peridotites, and so on. A specific feature of such masses is low stability, caused by numerous chaotic fractures and differently oriented tectonic faults up to $20-50 \mathrm{~m}$ thick, dividing the mass into structural blocks of various scale-hierarchical levels with a weak interblock coherency, which decreases to almost zero when moistened, namely when talcylike mylonite or serpophite fracture filler becomes soapy to the touch [2]. In addition, on outcrops, the serpentinized rocks are prone to accelerated weathering to small-block state with a dilatation increase in volume [3]. All this leads to the problems of ensuring the stability of mine workings and the choice of technological solutions, taking into account the whole com-

(C) Matayev A. K., Lozynskyi V.H., Musin A., Abdrashev R. M., Kuantay A. S., Kuandykova A. N., 2021 plex of patterns in the formation of the rock mass stress-strain state [4].

At the design stage, the main task is to select the location and laying-out of mine workings taking into account changes in the initial and secondary stress and deformation fields [5], as well as depending on the adopted development procedure and the mutual influence of mine workings in various geomechanical conditions [6].

At the stage of driving and fastening of mine workings on the deep horizons of DGOK mines, their stability is controlled in two main directions. The first is the limitation of the structural rock block mobility in the border rock mass around mine working by its deep bolting and cementation in the already formed roof arch. In addition, it should be supported with the help of "punctures" (preliminary strengthening of the rock mass along the mine working route, both along the arch and, possibly, along the entire perimeter) in order to ensure the optimal height of the rock mass cave above the roof and the zone of inelastic deformations around constructed mine working, on which the size of the negative influence zone of the conducted mine working on the neighbouring mine workings depends. Also, the risk should be minimized of the influencing concentrated overloading from the structural blocks movements of the border rock mass on the permanent mine working support [7]. The second direction is to reduce the stresses in the permanent support by minimizing the influence on the support of displacements of the mine working rock walls in the bottom hole zone [8].

The most effective methods include ensuring the stability of the bottom hole part of mine working due to its temporary fastening and the creation of a yieldable fixing space that takes 
over a certain part of the convergence of mine working rock walls in the process of moving away from the face [9]. The basics of the developed methods for calculating the frame metal support include the corresponding mathematical models of the stress state formation of an underground structure, based on the main provisions of the underground structures mechanics on the interaction of support and rock mass as elements of a single deformable system [10]. At the same time, the loads on the support are not set a priori, but are determined in the process of calculating the entire "support mass" system taking into account the properties of the rock mass deformation and the underground structure rigidity [11]. Geotechnical monitoring in assessing the stability of underground workings allows determining deformation characteristics of the rock mass [12].

The main peculiarities of the frame metal support static work are also taken into account, which has a non-circular outline in cross-section and can work in both rigid and yieldable modes. Since the underground structures effective operation is ensured only in conditions of full contact of the support with the mass, the technology for conducting mine workings should provide for a high-quality backfilling of the fixing space, and the applied lagging should have rigidity that ensures mine working stability between the installed support frames [13]. Then the support frames perceive the rock pressure, and, following the general theoretical concepts of the underground structures mechanics, the support from periodically arranged frames can be considered in the design scheme as an equivalent "quasi-continuous" layer in terms of rigidity (according to Prof. N.S. Bulychev's terminology). To fully implement the above conditions and technical solutions to ensure the underground mine workings stability, a methodology has been developed in this work for calculating the optimal support for the deep horizons of DGOK mines.

The purpose of the research is to predict the patterns in the formation of the stress-strain state (SSS) within the boundaries of different stope operations' influence on the horizon -480 $\mathrm{m}$ in block 20-28, taking into account the optimization of implementing the main technological processes.

To achieve this purpose, the following objectives were set and completed:

- analysis of mining-and-geological, as well as miningengineering conditions of mining at the $10^{\text {th }}$ Anniversary of Kazakhstan's Independence Mine;

- analysis and selection of a method and software for determining the rock mass stress-strain state;

- numerical modelling of the rock mass stress-strain state on the horizon $-480 \mathrm{~m}$ of the $10^{\text {th }}$ Anniversary of Kazakhstan's Independence Mine;

- predictive assessment of the mass stress-strain state, which is based on the use of effective numerical methods and which allows increasing the reliability of predicting the "mining and geomechanical" situation at the extraction area.

Methods. Mining-geological and mining-engineering conditions for the development of the $10^{\text {th }}$ Anniversary of Kazakhstan's Independence Mine. Depending on the mining-engineering conditions, mine workings and technological chambers are fastened in compliance with the timbering standard certificates developed at DGOK on the basis of the "Instructions for calculating loads on the support of mine workings in the conditions of DGOK mines". An engineering-geological data on the host rocks properties are analyzed based on the international ISRM standard.

For the substantiated application of the main measures aimed at reducing the increased rock pressure on the compound support and arch support, it is expedient to identify the intervals of rocks exposed to accelerated and intense weathering in the process of driving of each advance and capital workings by the core-sample of predrilled wells.

The sections and type of mine working support are determined depending on specific mining-geological and mining- engineering conditions. The conjugation of cuts and stope drift (cross-cuts) is performed using the metal frames with the roof lagging. All conjugations of horizontal mine workings of a rectangular raise and a rectangular (cross-type) intersection are fastened with a metal arch support (Fig. 1).

The diagonal development of stope operations on the horizon (block, panel) provides not only a reduction in the duration of mine workings operation in the bearing pressure zone, but also significantly influences the redistribution of rock pressure, contributing to an increase in the operational reliability of advance face entries. If, in the previously used schemes, the maximum horizontal stresses acted perpendicular to the longitudinal axis of the haulage cross-cut, then with the diagonal scheme of the development of stope works and combined cross-cut-drift preparation, the maximum horizontal stresses act at an angle of 35-500 to the axis of the haulage advance working. The duration of the rock pressure impact on the support of mine workings in some areas is reduced by 1.5-2 times. With this scheme, the number of operating blocks is increased, which makes it possible to control rock pressure and conduct repair work (re-fastening) on the horizon.

Within the mining allotment area, two types of groundwater are developed: pore water - in Cretaceous and Paleogene deposits and fissure water - in the rocky Paleozoic mass. Groundwaters in Cretaceous and Paleogene deposits have sporadic distribution. It does not have an independent significance in the formation of water inflows into underground mine workings. Fissure water developed in the rocky orebearing mass is the main source of flooding the mine workings and is subdivided into fissure-ground and fissure-vein. Its distribution is associated to the zones of open fracturing the metamorphosed intrusive rocks of basic and ultrabasic composition, represented by gabbro-amphibolites and serpentinites through dunites and peridotites. The heterogeneity of the mining-and-geological conditions of the rocks occurrence and an increase in the mining depth require constant monitoring and predicting the stress-strain state (SSS) of rock masses enclosing mine workings for various purposes and with different contours [7].

The choice of method and software for determining the SSS of the mass. To perform geomechanical modeling, the Rocscience software system of finite element analysis is used during the research. With the help of this software, which is a complex package of computational programs for finite element calculation of the stress-strain state of underground structures and foundations, it is possible to solve problems of engineering geomechanics, geotechnics and design [14]. Rocscience's RS2 software is a powerful 2D finite element program for application in mining practice. RS2 can be used for a wide range of engineering projects including the design of underground mine workings [15].

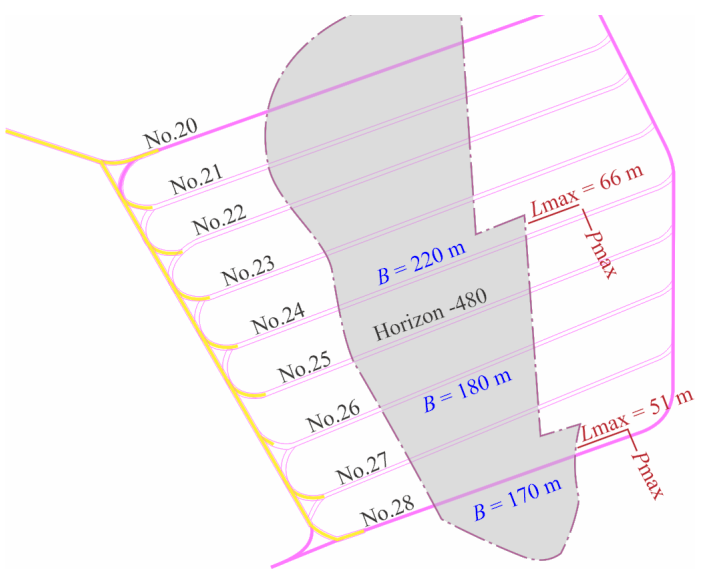

Fig. 1. Scheme for boundaries of the stope operations impact in the first stope block, $-480 \mathrm{~m}$ horizon 
The data obtained in the RS2 software are similar to the natural processes occurring in the conditions of the mineral deposit development. The software package has been widely used at many fields, since it allows taking into account such factors as the physical and mechanical properties of rocks and fractures, the presence of water, stress condition, parameters of mine workings, types of support, the influence of fixed loads, expected displacements, and so on [16].

This software is used at large mining companies such as JSC ArcelorMittal Temirtau, JSC Zhairem Mining and Processing Plant, LLP Orken Karazhal deposit of iron and manganese, LLP Nova Zinc and many other companies, both in the Republic of Kazakhstan and around the world [17, 18].

In the problems of modeling mathematical stress-strain state, a rock mass can be considered as a continuous elastic medium with specified mechanical properties [19]. This approach does not always reflect the real situation. However, for the mining practice problems related to the analysis of changes in the stress-strain state of a mass under the influence of technogenic impacts, the assumption of the elastic medium continuity allows obtaining results that are reasonably well consistent with practice [20]. For the numerical problem solution, the method of boundary integral equations is used. The following vertical stresses $\delta=\gamma H$ and horizontal stresses $\delta_{x}=\delta_{y}=$ $=\lambda \gamma H$ are taken as the parameters of the natural stress field $(H$ is mining depth; $\gamma$ is bulk density of rocks; $\lambda$ is horizontal stress ratio).

The existing failure theories make it possible to determine the rock destruction under any type of stress condition on the basis of experimental data obtained under any of the simplest types of loading [21]. When calculating, not only the physical and mechanical properties of rocks and the stresses acting in the mass are taken into account, but also the structural characteristics of the mass, as well as the degree of technogenic impact. The Hoek-Brown model with its distinctive advantage of nonlinearity is used as a model for the mass behaviour.

Taking into account the values of $\delta, C$ and $\varphi$ as parameters of the rectilinear envelope of the Mohr-Coulomb circles, the value of adhesion $C$ can be found from the expression, $\mathrm{MPa}$

$$
C=\delta / A,
$$

where $A=2 \cos \varphi / 1-\sin \varphi=2.85$, at $\varphi=20^{\circ}$ is linearization parameter, enveloping the Mohr-Coulomb circles, $C$ and $\varphi$ are respectively, adhesion and angle of inter-block friction of the studied rock mass volume, numerically equal to the values obtained in laboratory tests of samples.

Then the adhesion values $C$ at the values of $\varphi$ indicated above will be: for category of competence $\mathrm{V}-0.07 \mathrm{MPa}$; IV $-0.18 \mathrm{MPa}$; intermediate between IV and III $-0.35 \mathrm{MPa}$. For example, in accordance with the proposed methodology for the support erected at a depth of $H=900 \mathrm{~m}$ in rocks of IV category of competence, mathematical models, namely design curves were developed, the configuration and sizes of inelastic deformations around mine working were determined. The initial data taken for the calculations are given below.

Depth of field development is $900 \mathrm{~m}$; rough section of mine workings is $15.9 \mathrm{~m}^{2}$; rock mass deformation modulus $\left(E_{0}\right)$ is $5000 \mathrm{~Pa}$; adhesion factor $(C)$ is $0.18 \mathrm{MPa}$; internal friction angle $\varphi$ is 20 degrees; Poisson's ratio of rocks is 0.3 .

Results. Determining the zones of inelastic deformations and the coefficient of mine working stability margin. It should be noted that the stress-strain state of the mass is the main factor when determining the load on the underground structure fastening. Thus, the correctness of the fastening structure calculation largely depends on the idea of the stress-strain state of the rock mass and the mechanical processes that occur around the mine working.

When driving mine working in a rock mass, its initial stress-strain state is disturbed, that is, a redistribution of stresses and deformations occurs in the border zone of mine working. In practice, a new stress field is formed, character- ized by stress concentration along a predetermined mine working contour.

To determine the dimensions of inelastic deformation zones around mine working (the survey area is shown in Fig. 1), mathematical models were developed using the RS2 software, the results of which are shown in Fig. 2.

As it follows from the calculations, destruction zones from $4.4 \mathrm{~m}$ in the arch and up to $4.8 \mathrm{~m}$ in the bottom are formed around mine working. With a minimum section area of mine workings, the cross-section area of the plastic deformation zone and, hence, the potential volume of rock fall grow linearly with increasing depth.

For other sections of mine workings, this dependence is nonlinear. From the point of view of increasing the volume of rock fall into mine working, the most unreasonable cross-section is the section with the area $S=16.71$; this is indicated by the largest gain in the volume of rock fall with an increase in the depth of mine working placement.

The result of the stresses concentration around mine working is the creation of an inelastic deformation zone. These deformations develop in time and propagate deep into the mass. The rock deformations in the inelastic deformation zone displace the mine working contour. In turn, these rock contour shifts create the loads on fastening. If the ais rigid, and the load exceeds its bearing capacity, then it can be destroyed.

It is obvious that the specified peculiarity of the mine working shape influence on the size of the plastic deformation zone is qualitative. To concretize the degree of influence of the mine working shape on the size of the potential rock fall zone, the dependence of the ratio of the cross-section area of the plastic deformation zone in the sides of mine working to the section area of mine working has been revealed.

Due to the yieldable fastening, pressure can be avoided, and a zone of inelastic deformations can be formed around mine working. In this zone, as a result of landslides, a decrease in stresses occurs, therefore, in combination with a fastening, it can be used as a supporting structure, while performing the function of a relieving wall for the rocks of this inelastic deformation zone. Since any fastening has a certain yielding property, the zone of inelastic deformations stabilizes over time, that is, its propagation into the mass depth stops.

The most reasonable, with the minimum volumes of destroyed rocks on the mine working contour, is the mine working with the cross-section area $S=13.71 \mathrm{~m}^{2}$. This is indicated by the maximum values and the maximum gain in the rock fall volume, taking into account the depth of mine working placement. The most unreasonable, with the maximum volumes of destroyed rocks on the mine working contour, is the mine working with the cross-section area $S=16.71 \mathrm{~m}^{2}$; this is indi-

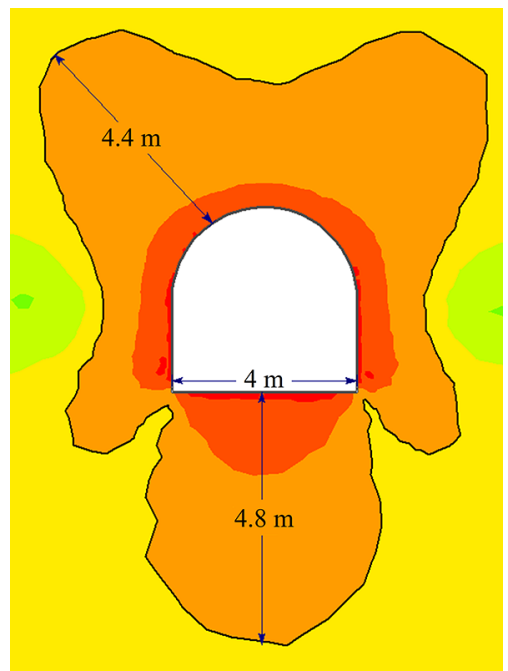

Fig. 2. Inelastic deformation zone around mine working 
cated by the maximum values and the maximum gain in the rock fall volume with an increase in the depth of mine working placement.

The results of modeling the coefficients of stability margin around mine working in its arch part, in the sides and in the bottom of mine working are shown in Fig. 3. The coefficients of stability margin around mine workings are summarized in Table 1.

The existing analytical solutions of geomechanical problems on the stress-strain state are mostly made for round mine workings. This is due, in particular, to the fact that the description of a circular contour in such problems makes it easier to find a solution. At the same time, real mine workings in mines have contour outlines that are different from the round one. Thus, the existing solutions can be extended to real objects with a known degree of probability.

Predicting the geomechanical situation development in the rock mass within the boundaries of the stope operations influence. To predict the sizes of the destruction zones around mine working during driving operations across the strike, along the strike and on the diagonal of the ore body, the mathematical models were developed in the RS2 software, the results of which are shown in Fig. 4.

According to the results of mathematical modeling by the finite element method, the predicted zones of inelastic deformation (IDZ) are as follows: when driving mine workings
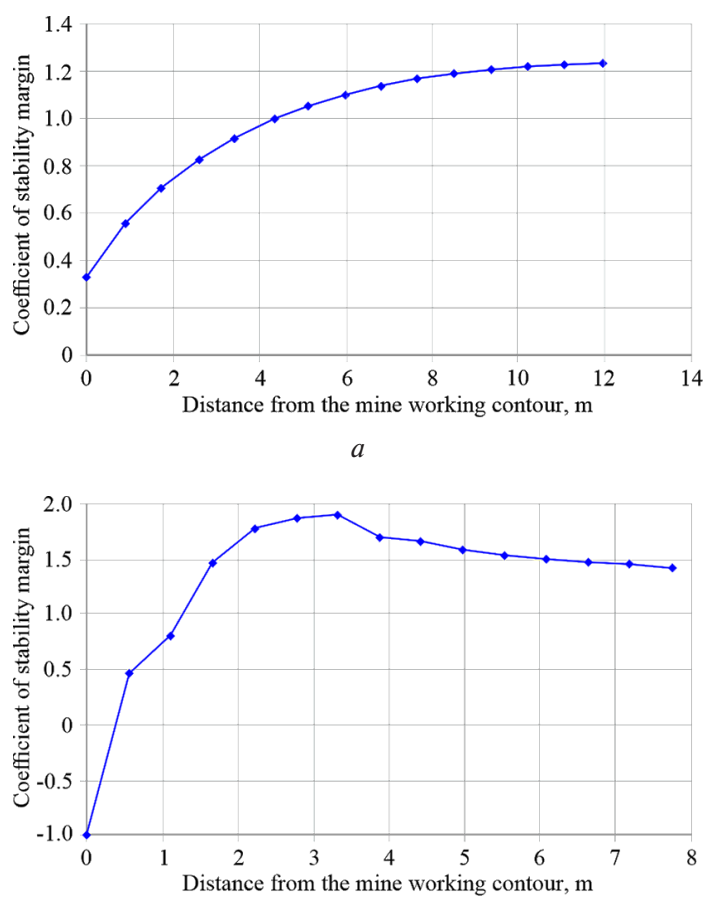

b

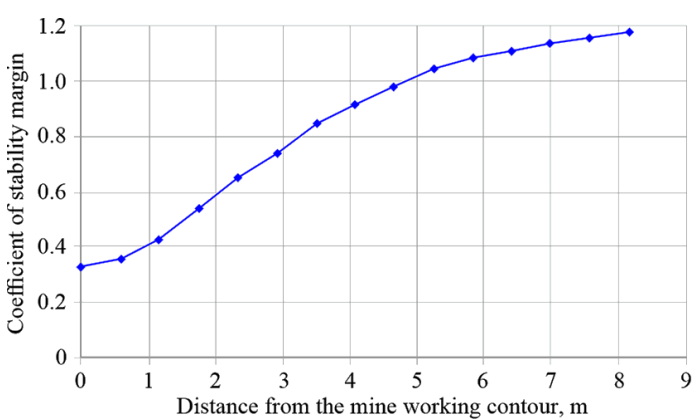

Fig. 3. Graphs of changes in the coefficients of stability margin:

$a$-in the arch part of mine working; $b$ - in the sides of mine working; $c$ - in the bottom of mine working
Table 1

Coefficients of mine workings stability

\begin{tabular}{|c|c|c|c|}
\hline \multirow{2}{*}{$\begin{array}{c}\text { Distance from } \\
\text { the mine working } \\
\text { contour, } \mathrm{m}\end{array}$} & \multicolumn{3}{|c|}{ Coefficient of stability margin } \\
\cline { 2 - 4 } & In the roof & In the sides & In the bottom \\
\hline 1 & 0.6 & 0.7 & 0.3 \\
\hline 2 & 0.7 & 1.5 & 0.6 \\
\hline 3 & 0.81 & 1.8 & 0.75 \\
\hline 4 & 1.0 & 1.6 & 0.91 \\
\hline 5 & 1.05 & 1.5 & 1.05 \\
\hline 6 & 1.1 & 1.4 & 1.1 \\
\hline 7 & 1.11 & 1.35 & 1.11 \\
\hline 8 & 1.18 & 1.3 & 1.19 \\
\hline 9 & 1.2 & 1.3 & 1.19 \\
\hline 10 & 1.22 & 1.3 & 1.19 \\
\hline 11 & 1.24 & 1.3 & 1.19 \\
\hline 12 & 1.26 & 1.3 & 1.19 \\
\hline
\end{tabular}

across the strike, IDZ is equal to $4.3 \mathrm{~m}$ in the arch part, $4.8 \mathrm{~m}$ in the bottom; when driving mine workings on the diagonal, IDZ is equal to $5.0 \mathrm{~m}$ in the arch part, $5.5 \mathrm{~m}$ in the bottom; when driving mine workings along the strike, IDZ is equal to $5.6 \mathrm{~m}$ in the arch part, $5.8 \mathrm{~m}$ in the bottom. Based on this, it can be argued that mine workings will be the most stable when driving across the strike of the ore body. As the model is loaded, the type of destruction changes and, as a rule, destruction of the element itself occurs when the ultimate compression strength is exceeded.

Fig. 5 below shows the numerical analysis results on determining the zones of possible destruction in the interval between cross-cuts $20-28$.

As it follows from the performed computer modeling of a mine working with a section of $16 \mathrm{~m}^{2}$ (width $4 \mathrm{~m}$, height $4 \mathrm{~m}$ ), the zones of inelastic deformation (destruction) from $4.4 \mathrm{~m}$ in the arch and up to $4.8 \mathrm{~m}$ in the bottom are formed around mine working.

Prediction of inelastic deformation zones during driving operations along the strike, across the strike and on the diagonal of the ore body has revealed that driving of mine workings across the strike of the ore body (driving by cross-cuts) is the most reasonable.

As a result of the research, the inelastic deformation zones between axes 20-28 have been found, from which it can be seen that the maximum destruction zones are observed in axis No. 24, and the zones of the least destruction are in axes No. 20 and No. 28. This is represented in Fig. 6.

Based on the predictive assessment results of mine workings stability margin, it should be assumed that the stability margin of the driven mine workings in the area of stope operations is below the minimum permissible. Therefore, caving and an increase in the load on the support are possible. Predicting the dangerous rock pressure manifestations with insufficient knowledge about the geomechanical conditions of mining operations, which are inherent at the initial stage of mining the field, can be performed based on the results of mathematical modeling of the stress-strain state in the vicinity of mine workings. On its basis, it is possible to give a preliminary assessment of the border zone state and trace the nature of its change at various stages of mineral deposits development. The accuracy of the obtained estimates is determined by the correspondence of the parameters adopted in the computational model to the real state with the properties of the mass.

Conclusions. A predictive assessment of the mass stressstrain state is performed, which is based on the use of effective 


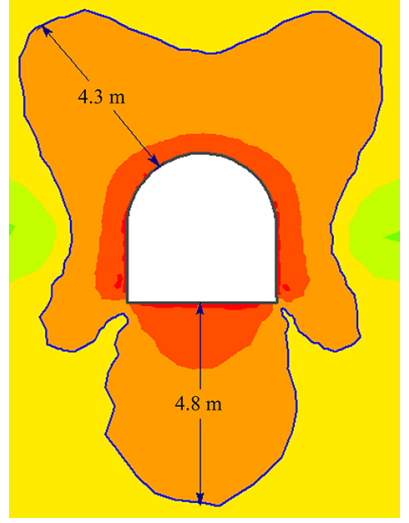

$a$

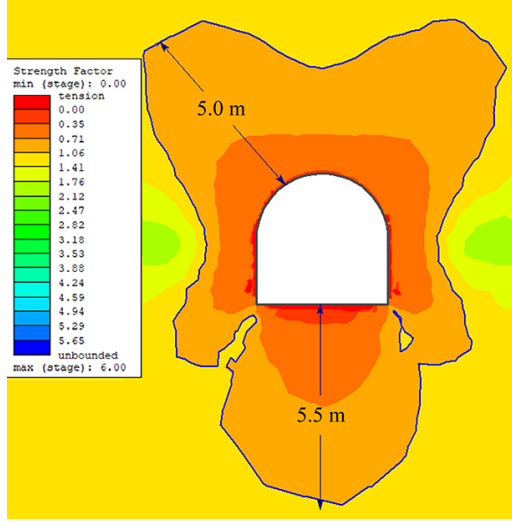

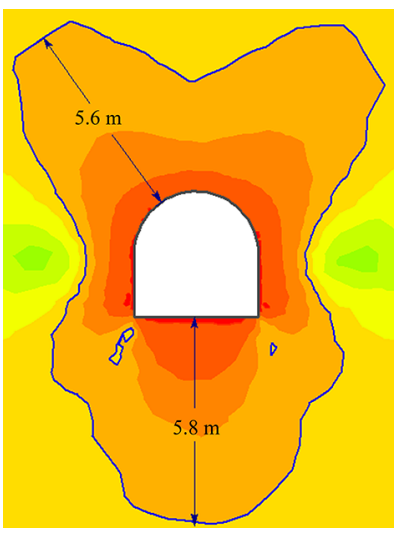

$c$

Fig. 4. Predicted zone of inelastic deformation (width $4 m$, height $4 m$ ):

$a$ - when driving mine workings across the strike; $b$ - when driving mine workings on the diagonal; $c$ - when driving mine workings along the strike
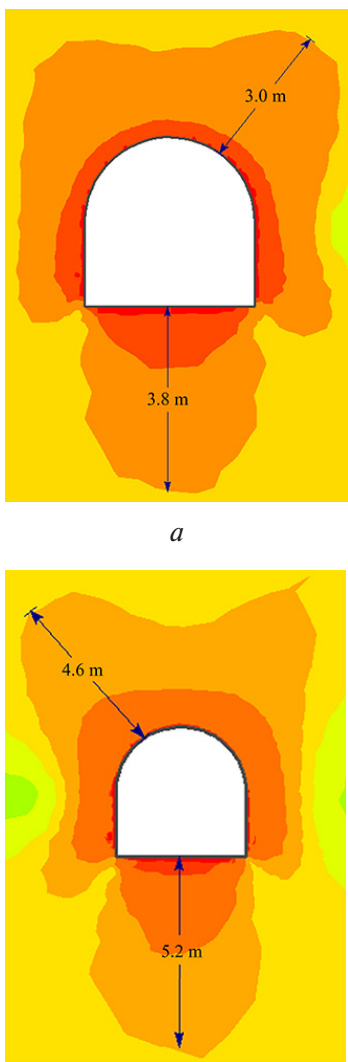

$d$

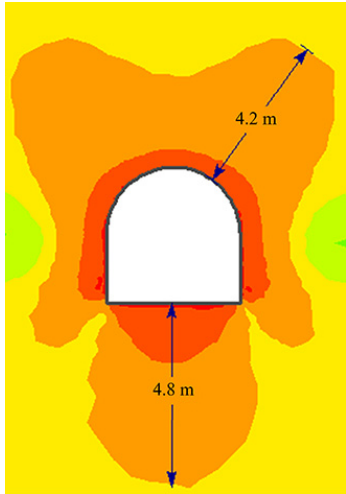

$g$
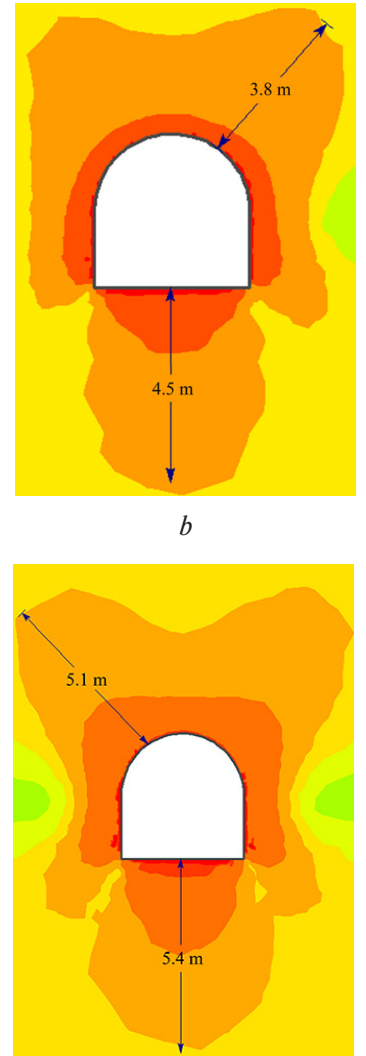

$e$

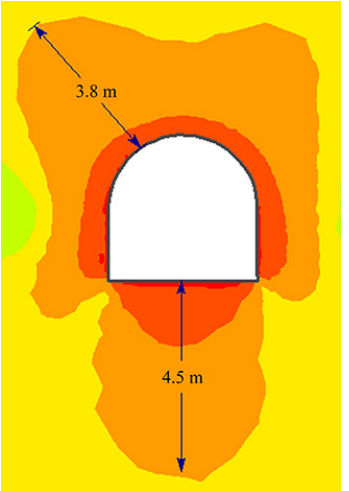

$h$
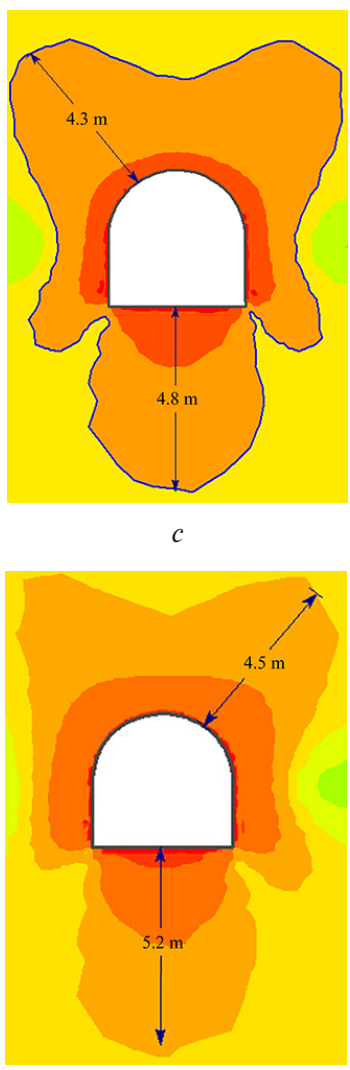

$f$

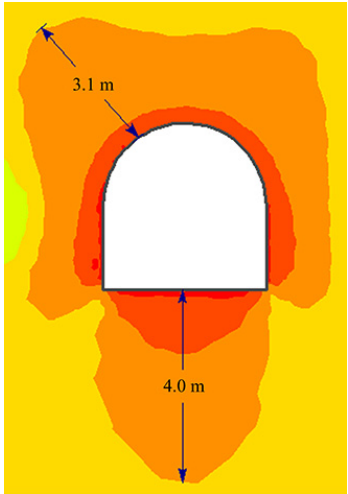

$i$

Fig. 5. Predicted zone of inelastic deformation along the axis:

$a-N o .20 ; b-N o .21 ; c-N o .22 ; d-N o .23 ; e-N o .24 ; f-N o .25 ; g-N o .26 ; h-N o .27 ; i-N o .28$ 


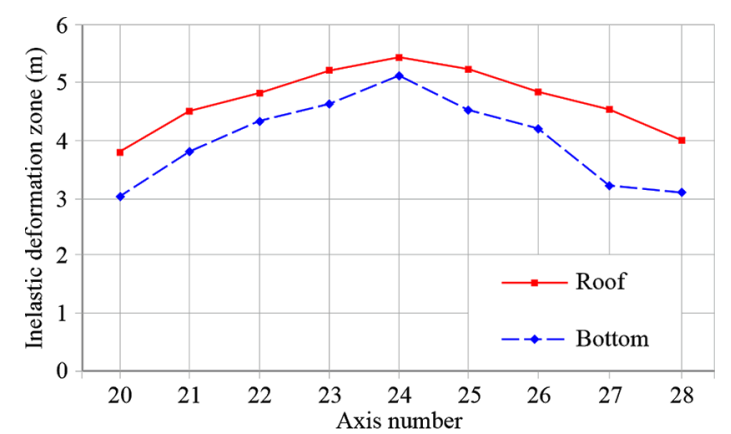

Fig. 6. The results of determining the zones of inelastic deformation between axes (cross-cuts) 20-28

numerical methods and which allows increasing the reliability of predicting the "mining and geomechanical" situation at the extraction area.

Numerical modelling of the rock mass stress-strain state and the calculation of the load-bearing capacity of the support types used at the mine are performed with the help of the RS2 software. This program, based on the finite element method in a two-dimensional formulation, makes it possible to take into account a significant number of factors influencing the mass state. The Hoek-Brown model with its distinctive advantage of nonlinearity is used as a model for the mass behaviour.

The research shows that the method for increasing the reliability of fastening by installing joists with increased resistance to yield, providing a higher resistance of the support frames, does not lead to positive results. Thus, the developed method for modeling the underground structure stress state and the calculations performed on its basis make it possible to substantiate the most effective way to control the mine workings stability during their driving, construction and operation at deep horizons of DGOK mines with the help of preliminary (advanced) strengthening of the border rock mass.

As follows from the calculations, the zones of inelastic deformation (destruction) from $4.4 \mathrm{~m}$ in the arch part and up to $4.8 \mathrm{~m}$ in the bottom are formed around mine working. The zones of inelastic deformation between the axes 20-28 have been determined, the results of which show that the maximum zones of destruction are observed in axis No. 24, and the zones of the least destruction are in axes No. 20 and No. 28.

Prediction of inelastic deformation zones during driving operations along the strike, across the strike and on the diagonal of the ore body revealed that driving of mine workings across the strike of the ore body (driving by cross-cuts) is the most reasonable.

To clarify the predicting assessment of the mass stressstrain state using the finite element method, it is recommended to perform in-situ measurements. Predicting assessment of mine workings stability margin is performed before and after stope operations. Based on its results, it can be assumed that the stability margin of the mine workings driven in the stope zone is below the minimum permissible, therefore, caving and an increase in the load on the support are possible.

Acknowledgements. We would like to express our gratitude to all the editorial staff and reviewers for the quality work on our material. We are pleasantly surprised by the prompt and wellorganized feedback from the editors. We wish the journal prosperity and look forward to further fruitful cooperation! Of special note is the well-organized and well-coordinated team work. We would like to express our gratitude to Arystan Ibatolla Daiyrovich for valuable advice in planning the research and recommendations for the paper design. In addition, the authors are also grateful to colleagues for their help in the work on the manuscript.

\section{References.}

1. Abdiev, A., Mambetova, R., Abdiev, A., \& Abdiev, S. (2020). Development of methods for assessing the mine workings stability. E3S
Web of Conference, (201), 01040. https://doi.org/10.1051/e3sconf/202020101040.

2. Balek, A. E., \& Panzhin, A.A. (2017). The solution of problems of geomechanical maintenance of underground mining at chromite deposits of Donskoy Mining Processing Plant. Innovatsionnye geotekhnologii pri razrabotke rudnykh i nerudnykh mestorozhdeniy, (18), 241249. Retrieved from http://www.ursmu.ru/upload/doc/2018/11/30/ sbornik ingeo-2017.pdf $\#$ page $=241$.

3. Sultanov, M.G., Mataev, A.K., Kaumetova, D.S., Abdrashev, R. M., \& Kuantay, A. S. (2020). Development of the choice of types of support parameters and technologies for their construction at the "Voskhod" field. Ugol', (10), 17-21. https://doi.org/10.18796/00415790-2020-10-17-21.

4. Abdiev, A. R., Mambetova, R. S., \& Mambetov, S. A. (2017). Geomechanical assessment of Tyan-Shan's mountains structures for efficient mining and mine construction. Gornyi Zhurnal, (4), 23-28. https://doi.org/10.17580/gzh.2017.04.04.

5. Rysbekov, K., Toktarov, A., Kalybekov, T., Moldabayev, S., Yessezhulov, T., \& Bakhmagambetova, G. (2020). Mine planning subject to prepared ore reserves rationing. E3S Web of Conference, (168), 00016. https://doi.org/10.1051/e3sconf/202016800016.

6. Lozynskyi, V., Medianyk, V., Saik, P., Rysbekov, K., \& Demydov, M. (2020). Multivariance solutions for designing new levels of coal mines. Rudarsko Geolosko Naftni Zbornik, 35(2), 23-32. https:// doi.org/10.17794/rgn.2020.2.3.

7. Matayev, A. K., Kainazarova, A. S., Arystan, I. D., Abeuov, Ye., Kainazarov, A. S., Baizbayev, M. B., Demin, V. F., \& Sultanov, M. G. (2021). Research into rock mass geomechanical situation in the zone of stope operations influence at the $10^{\text {th }}$ Anniversary of Kazakhstan's Independence mine. Mining of Mineral Deposits, 15(1), 1-10. https:// doi.org/10.33271/mining15.01.042.

8. Arystan, I. D., Baizbaev, M. B., Mataev, A. K., Abdieva, L. M., \& Bogzhanova, Z. K. (2020). Selection and justification of technology for fixing preparatory workings in unstable massifs on the example of the mine " 10 years of Independence of Kazakhstan. Ugol', (06), 1014. https://doi.org/10.18796/0041-5790-2020-6-10-14.

9. Dychkovskyi, R., Shavarskyi, Ia., Saik, P., Lozynskyi, V., Falshtynskyi, V., \& Cabana, E. (2020). Research into stress-strain state of the rock mass condition in the process of the operation of double-unit longwalls. Mining of Mineral Deposits, 14(2), 85-94. https://doi. org $/ 10.33271 /$ mining 14.02 .085 .

10. Bondarenko, V., Kovalevs'ka, I., Svystun, R., \& Cherednichenko, Y. (2013). Optimal parameters of wall bolts computation in the united bearing system of extraction workings frame-bolt support. Annual Scientific-Technical Colletion Mining of Mineral Deposits, 5-10. https://doi.org/10.1201/b16354-2V.

11. Piwniak, G. G., Bondarenko, V.I., Salli, V.I., Pavlenko, I. I., \& Dychkovskiy, R. O. (2007). Limits to economic viability of extraction of thin coal seams in Ukraine. Technical, Technological and Economic Aspects of Thin-Seams Coal Mining International Mining Forum 2007, 129-132. https://doi.org/10.1201/noe0415436700.ch16.

12. Małkowski, P., Niedbalski, Z., Majcherczyk, T., \& Bednarek, L. (2020). Underground monitoring as the best way of roadways support design validation in a long time period. Mining of Mineral Deposits, 14(3), 1-14. https://doi.org/10.33271/mining14.03.001.

13. Kuanyshbekovna, M.M., Krupnik, L., Koptileuovich, Y.K., Mukhtar, E., \& Roza, A. (2016). The system is "roof bolting-mountain". International Journal of Applied Engineering Research, 11(21), 10454-10457.

14. Sun, S., Li, S., Li, L., Shi, S., Wang, J., Hu, J., \& Hu, C. (2018). Slope stability analysis and protection measures in bridge and tunnel engineering: a practical case study from Southwestern China. Bulletin of Engineering Geology and the Environment, 78(5), 3305-3321. https:// doi.org/10.1007/s10064-018-1362-y.

15. Dinh, V. D., Do, N. A., Bruland, A., \& Dias, D. (2020). Estimating the Radial Displacement on the Tunnel Boundary within Efficient Working Area of Rock Tunneling Quality Index (Q-System). Proceedings of the International Conference on Innovations for Sustainable and Responsible Mining, 81-90. https://doi.org/10.1007/978-3-03060839-2 5 .

16. Kumar, S., \& Pandey, H. K. (2021). Slope Stability Analysis Based on Rock Mass Rating, Geological Strength Index and Kinematic Analysis in Vindhyan Rock Formation. Journal of the Geological Society of India, 97(2), 145-150. https://doi.org/10.1007/s12594-021$1645-\mathrm{y}$.

17. Baibatsha, A., Dussembayeva, K., Bekbotayeva, A., \& Abdullayeva, M. T. (2018). Tails of enrichment factories as the technogenic mineral resources. International Multidisciplinary Scientific GeoConfer- 
ence Surveying Geology and Mining Ecology Management, SGEM, 18(1), 519-526. https://doi.org/10.5593/sgem2018/1.1/s01.066.

18. Omarova, G., Baibatsha, A., \& Abdykirova, G. Z. (2019). Flotation enrichment of enrichment factory tailings for use as technogenic ore. International Multidisciplinary Scientific GeoConference Surveying Geology and Mining Ecology Management, SGEM, 19(1), 195-202. https://doi.org/10.5593/sgem2019/1.1/s01.024.

19. Khomenko, O., Kononenko, M., \& Petlyovanyy, M. (2014). Investigation of stress-strain state of rock massif around the secondary chambers. (2014). Progressive Technologies of Coal, Coalbed Methane, and Ores Mining, 253-258. https://doi.org/10.1201/b17547-43.

20. Galiyev, D. A., Uteshov, E.T., \& Tekenova, A. T. (2020). Digitalization of technological and organizational processes of mining operations due to the implementation of the installation system and accounting the key indicators. News of the National Academy of Sciences of the Republic of Kazakhstan, Series of Geology and Technical Sciences, 5(443), 47-53.

21. Abdiev, A., Mambetova, R., Abdiev, A., \& Abdiev, Sh. (2020). Studying a correlation between characteristics of rock and their conditions. Mining of Mineral Deposits, 14(3), 87-100. https://doi. org/10.33271/mining14.03.087.

\section{Обгрунтування оптимального виду кріплення гірничих виробок на основі математичного моделювання напруженого стану підземних конструкщій}

\author{
А. К. Матаєв ${ }^{1}$, В. Г. Лозинський ${ }^{2}$, А. Мусін ${ }^{1}$, \\ P. М. Абдрашев ${ }^{3}$, А. С. Куантай ${ }^{3}$, А. Н. Куандикова ${ }^{3}$ \\ 1 - Карагандинський державний технічний університет, \\ м. Караганда, Республіка Казахстан, e-mail: mataev. \\ azamat@mail.ru \\ 2 - Геологічний концерн «Геобіт», м. Хжанув, Республі- \\ ка Польща \\ 3 - Актюбінський регіональний університет імені Р. Жу- \\ банова, м. Актобе, Республіка Казахстан
}

Мета. Прогноз формування напружено-деформованого стану (НДС) в масиві гірських порід в межах впливу очисних робіт на гор. -480 м в осях 20-28 на шахті «ДНК».
Методика. Геолого-інженерні дані властивостей вміщуючих порід проаналізовані на базі міжнародного стандарту ISRM. Чисельне моделювання напруженодеформованого стану масиву гірських порід і розрахунок несучої здатності комбінованого (анкер + торкретбетон + сітка) та аркового кріплення, що застосовуються на шахті, виконано у програмі RS2, яка працює на основі методу скінченних елементів у двовимірній постановці та дає можливість урахувати значну кількість чинників, що впливають на стан гірського масиву.

Результати. Виконані розрахунки показали, що відпір кріплення виявляється незрівнянно малим у порівнянні 3 величинами компонент поля початкових напружень у масиві. У таких умовах проведення заходів зі зміцнення масиву навколо виробки може бути більш ефективним, ніж встановлення більшої кількості рам або перехід на більш масивні профілі кріплення.

Наукова новизна. Представлені результати математичного моделювання та розрахунків напруженого стану підземних конструкцій «кріплення - законтурний масив», розроблені для складних гірничо-геологічних і геомеханічних умов проведення, кріплення та експлуатації гірничих виробок на глибоких горизонтах шахт Донського ГЗК. На основі проведених досліджень обгрунтовано, в якості пріоритетного способу управління стійкістю виробок, попереднє (випереджаюче) закріплення приконтурного масиву гірських порід у зоні непружних (руйнуючих) деформацій.

Практична значимість. Результати досліджень можуть бути застосовані при створенні геомеханічної моделі родовища та проектуванні стійких способів кріплення гірничих виробок.

Ключові слова: шахта, кріплення виробок, напруженодеформований стан, зона непружних деформації, рамне кріплення

Recommended for publication by Z. R. Malanchuk, Doctor of Technical Sciences. The manuscript was submitted 15.01.21. 